\title{
From Washington to Luxembourg... Stopping Over at Strasbourg? Enforcement of ICSID Awards under EU Law
}

\author{
José CABRERA RODRÍGUEZ*
}

\begin{abstract}
A conflicting interplay between EU Law and International Investment Law has been brought to light in recent years. This paper is purported to argue that such conflicting interplay may be indirectly mediated by the relationship between the European Convention of Human Rights and the Washington Convention on the Settlement of Investment Disputes between States and Nationals of Other States.
\end{abstract}

Keywords: EU Law - ECHR - ICSID - International Investment Law - Investment Arbitration

\section{(A) INTRODUCTION}

One of the main empirical findings on which the current narratives on the fragmentation of international law have been premised is the ascertainment that one and the same issue may be covered simultaneously by different treaty regimes. The legal treatment accorded to this issue may vary from one regime to another, all the more so when these regimes have settled adjudicatory bodies, whose international jurisdictions may then overlap².

By simultaneously covering the same issue, treaty regimes may interrelate under different perspectives. It is a truism to say that, where unavoidably inconsistent results are reached under overlapping regimes, a treaty conflict may arise. Among all the possible perspectives under which treaty regimes may relate to each other, this conflictual relationship is certainly the one at which classical legal scholarship has traditionally focused most attention?

\footnotetext{
Professor of Public International Law, Postgraduate researcher, Universitat Pompeu-Fabra, Barcelona; Attorney at Hoyng Rokh Monegier. Email: josecabrerarodriguez@outlook.com.

I See International Law Commission, 'Report of the Study Group on Fragmentation of International Law: Difficulties Arising from the Diversification and Expansion of International Law', UN Doc A/CN.4/L.682, I3 April 2006, paras 2I-22, II6-II8 (arguing that treaties cannot be prevented from overlapping by being classified on the criterion of subject-matter since the same set of facts can be simultaneously governed by several treaties relating to apparently disparate fields).

2 See V. Lowe, 'Overlapping Jurisdiction in International Tribunals', 20 Australian Yearbook of International Law (1999) 19I-204; Joost Pauwelyn, 'Forum Shopping before International Tribunals: (Real) Concerns, (Im)Possible Solutions', 42(I) Cornell International Law Journal (2009) 77-II8 (at 84, arguing that 'there is no top-down division of labor among international tribunals. The "international judiciary" is such that the authority of each body is limited by its own governing instruments, and there is no statute defining the authority of tribunals in relation to each other').

3 See H. Kelsen, Principles of International Law (New York: Rinehart, 1952) 36I et seq; M. Zuleeg, 'Vertragskonkurrenz im Völkerrecht. Teil I: Verträge zwischen souveränen Staaten', 20 German Yearbook of International Law (1977) 246-276 and 'Vertragskonkurrenz im Volkerrecht. Teil II: Verträge zwischen beliebigen Volkerrechts- subjekten', 27 German Yearbook of International Law (1984) 367-385; G. Binder, Treaty Conflict and Political Contradiction: The Dialectic of Duplicity (Praeger, New York, 1988). Contemporary scholars have kept addressing the issue. See J. B. Mus, Verdragsconflicten voor de Nederlandse recbter (WEJ Tjeenj Willink, Deventer, 1996) and 'Conflicts between Treaties in International Law', 45 Netherlands International Law Review (1998) 208-232; J. Klabbers, Treaty Conflict and the European Union (CUP,
} 
Yet, on the opposite side of the continuum, there is also the case where treaty regimes may act concurrently, reciprocally reinforcing each other. Mutual supportiveness, so reads the concept coined by recent scholarship for qualifying this relationship ${ }^{4}$, may emerge through the interplay of different treaty regimes in areas of functional convergence. These areas are not precluded from eventually appearing even between regimes related to seemingly disparate subject-matters 5 . For by functional convergence is meant here a certain degree of synergy, by which the normative content of one treaty may operate, not at the expense of another treaty, but instead spontaneously reinforcing the fulfillment of the latter, regardless of whether or not both treaties share similar normative values or policy objectives ${ }^{6}$.

This article is purported to briefly argue that such a relationship may be found, at least in the terms that will be here suggested, between the European Convention of Human Rights ('ECHR'), on the one hand, and the Washington Convention on the Settlement of Investment Disputes between States and Nationals of Other States ('ICSID Convention'), on the other.

The ICSID Convention provides a procedural system under which disputes arising between foreign investors and their host States are adjudicated by arbitral tribunals on the basis of international investment agreements ${ }^{7}$. Arbitral awards rendered within this framework ('ICSID awards') are claimed to be final and binding on the parties by Article 53(I) of the ICSID Convention, and every State party is mandated by Article 54(I) to recognize them and to enforce in its territories the pecuniary obligations imposed by the awards 'as if it were a final judgment of a court in that State's.

Cambridge, 2009); S. Ranganathan, Strategically Created Treaty Conflicts and the Politics of International Law (CUP, Cambridge, 20I4).

4 See N. Matz-Lück, 'Harmonization, Systemic Integration and 'Mutual Supportiveness' as Conflict-Solution Techniques - Different Modes of Interpretation as a Challenge to Negative Effects of Fragmentation?', I7 Finnish Yearbook of International Law 2006 (2008), 39-53; R. Pavoni, 'Mutual Supportiveness as a Principle of Interpretation and Law-Making: A Watershed for the 'WTO-and-Competing-Regimes' Debate?', 2I(3) European Journal of International Law (2010) 649-679.

5 See W. Bradnee Chambers, Interlinkages and the effectiveness of multilateral environmental agreements (United Nations University, Tokyo/New York/Paris, 2008) at 154 (explicitly arguing that 'cooperation is not only reserved for treaties under what is perceived as similar branches of international law, such as international environmental law, but that positive cooperation between conflicting treaties across branches of international law can also increase treaty effectiveness'). See also A. Cassese, 'Remarks on Scelle's Theory of Role Splitting (dédoublement fonctionnel) in International Law', I European Journal of International Law (1990) 210-23I, at 210 (pointing out that international regimes 'do not live by themselves, each in its own area, but intersect and overlap with each other').

6 See W. Bradnee Chambers, supra, n. 5, at 138 (similarly explaining that ' $[\mathrm{t}]$ here must already be some predisposition among treaties towards making the interlinkage a potentially beneficial endeavour; generally, such predispositions would take the form of a normative or functional connection, a common subject area, a shared issue or, in some cases, a conflict').

7 International investment agreements may be defined as treaties by which 'two or more states agree to certain legal rules to govern investments undertaken by nationals of one treaty party in the territory of another treaty party'. See J. W. Salacuse, The Law of Investment Treaties (OUP, Oxford, 2015), at I4.

8 Article $53(\mathrm{I})$ of the ICSID Convention provides that " $\mathrm{t}]$ he award shall be binding on the parties and shall not be subject to any appeal or to any other remedy except those provided for in this Convention. Each party shall abide by and comply with the terms of the award except to the extent that enforcement shall have been stayed pursuant to the relevant provisions of this Convention.'. And the full wording of Article 54(I) provides that "[e]ach Contracting State shall recognize an award rendered pursuant to this Convention as binding and enforce the pecuniary obligations imposed by that award within its territories as it were a final judgment of a court in that State'. 
As for the ECHR, the enforcement of arbitral awards by domestic courts of its State parties appears to be protected under both Article 6 of the ECHR and Article I of Protocol No I to the ECHR, as interpreted by the European Court of Human Rights ('ECtHR'). Under Article 6(I) of the ECHR, the failure to enforce arbitral awards may also tantamount to a breach of the right to enforcement of final court decisions, to which awards have been equated for the purposes of judicial protection'. Under Article I of Protocol No I to the ECHR, awards have been considered to constitute a property on which States may unlawfully interfere by denying enforcement ${ }^{\mathrm{ro}}$.

Under this scenario, all the pieces seem to be in place for a positive interaction to operate between the ECHR and the ICSID Convention, since the former may concurrently support the enforcement of arbitral awards rendered under the latter, as long as such enforcement is sought before the courts of State parties to both treaties. Yet the proposed argument will be taken a step further by exploring the effects that the mutually supportive interplay between the ECHR and the ICSID Convention might indirectly exert on a third treaty regime, namely that of the European Union ('EU').

This second step is premised on the fact that all the Member States of the EU are State parties to the ECHR and, save for Poland, also to the ICSID Convention. This threefold treaty overlapping is likely to be all the more complex given the disparate relationships established by EU law with the ECHR, on the one hand, and with the ICSID Convention, on the other.

Whereas the ECHR has been incorporated as a constitutional pattern for the protection of fundamental rights within the framework of $\mathrm{EU}$ law $\mathrm{aw}^{\mathrm{II}}$, a much more conflicting interplay seems to have emerged between the latter and the ICSID Convention ${ }^{12}$. Although the problematic interaction between EU law and international investment agreements, to which the ICSID Convention is intended to serve, dates originally back to the so-called 'BITs cases' ${ }^{\text {I3 }}$, the conflicting interplay has

9 See ECtHR, Regent Company v Ukraine [2008].

Io See ECtHR, Stran Greek Refineris and Stratis Andreadis v Greece [1994]; Kin-Stib o $\sim$ Majkić v Serbia [2010].

II See B. De Witte, 'The Use of the ECHR and Convention Case Law by the European Court of Justice', in P. Popelier, C. Van de Heyning and P. Van Nuffel (eds), Human Rights Protection in the European Legal Order: The Interaction between the European and the National Courts (Intersentia, Cambridge/Antwerp/Poland, 20II) I7-34; J. L. Murray, 'The Influence of the European Convention on Fundamental Rights on Community Law', 33(5) Fordham International Law Journal (20II) I388-I422, at I394-I395 (noting that '[s]ince the mid-I990s in particular, the [EU] Court of Justice has increasingly looked to the European Convention on Human Rights for inspiration as to the nature and scope, or even existence, of fundamental rights in Community law, recognized the preeminent position of the Convention by I99I [in the ERT case]. In doing so, the [EU] Court of Justice has adopted a somewhat deferential position to the Strasbourg Court in the interpretation of fundamental rights that are contained in the Convention'). In its Opinion in the mentioned ERT case, Advocate General Lenz even stated that ' $[t]$ he rules of the Convention are to be regarded as part of the Community legal order' (para i5).

I2 For an overview, see S. Hindelang, 'Repellent Forces: The CJEU and Investor-State Dispute Settlement', 53 Archiv des Völkerrechts (2015) 68-89.

I3 See European Court of Justice, Case C-205/06, Commission v Austria [2009] ECR I-I30I; Case-249/o6, Commission v Sweden [2009] ECR I-I335; and Case C-II8/07, Commission v Finland [2009] I-I0889. In these decisions, commonly known as the 'BITs cases', free capital transfer clauses contained in bilateral investment treaties ('BITs') concluded with non-EU countries by Austria, Sweden and Finland prior to their accession to the EU were deemed incompatible with the powers conferred upon the EU Council to restrict free movement of capital to and from non-EU countries. Although former Art 307(I) of the European Community Treaty [now Art 35I(I) of the Treaty on Functioning of the European Union, 'TFEU'] confirmed pre- accession treaties concluded with non-EU countries by Member States to remain in force, Austria, Sweden 
dramatically increased in recent years. This might be due to several factors, the main among them being the new EU policy emerging in the field of foreign direct investment since the Lisbon Treaty ${ }^{\mathrm{I}}$, as well as a handful of proceedings conducted before arbitral tribunals on the basis of bilateral investment treaties ('BITs') concluded between EU Member States prior to their accession to the EU and considered by the European Commission to be incompatible with EU law ${ }^{15}$. This conflicting interplay has recently reached a critical point as a consequence of one of these proceedings, namely Micula $v$ Romania ${ }^{16}$. The European Commission has explicitly mandated Romania not to comply with the ICSID award rendered against it for considering that paying the sum awarded to the claimants would amount to granting of state aid prohibited by EU law ${ }^{17}$.

What will be here suggested is that, under this scenario, the ECHR may intermediate in the relationship between EU law and the ICSID Convention by according ICSID awards a relevant status under its own normative framework. Should ICSID awards be granted protection under Articles I of Protocol No I and 6 of the ECHR, then EU law would be bound to recognize such status and conceive their enforcement as a fundamental rights issue.

The argument proceeds in three stages. Part I examines whether and under which conditions ICSID awards may be accorded a specific status under the ECHR. Part II then analyses whether and to what extent EU law may be bound by the ECHR as for the legal status accorded to ICSID awards

and Finland were hold not to have taken appropriate steps required by former Article 307(2) [now Article 35I(2) TFEU] to remove the referred incompatibilities.

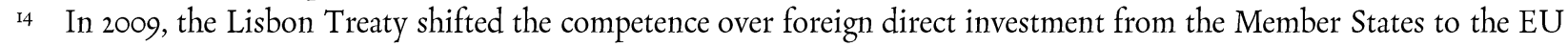
as part of the common commercial policy (Article 207 TFEU). See G. A. Bermann, 'Reconciling European Union Law Demands with the Demands of International Arbitration', 34(5) Fordham International Law Journal (20II) II93-I2I6, at I2I4 (pointing to the the new EU policy emerging in this field as a source of conflict and arguing that 'ii]t is not too soon to recognize that Member States judiciaries may come to face dilemmas created by conflicting signals from the ... [ICSID Convention] on the one hand and the foreign direct investment law and policy of the EU on the other... [T] he demands that EU law has imposed thus far in the foreign investment field have been mostly marginal. But as substantive EU policies in the field take shape, Member State judges will experience greater demands emanating from EU law').

is The European Commission has intervened in some of these proceedings as amicus curiae (AES $v$ Hungary; Electrabel $v$ Hungary; Micula $v$ Romania) in order to argue that pre-accession intra EU-BITs have been superseded by the EU treaties and that arbitral tribunals lack jurisdiction to decide those disputes. Furthermore, in two currently ongoing proceedings against Spain before ICSID tribunals (Antin $v$ Spain, ICSID Case No. ARB/I3/3I; Eiser $v$ Spain, ICSID Case No. $\mathrm{ARB} / \mathrm{r} 3 / 36$ ), amicus-petitions submitted by the European Commission have even been denied by both arbitral tribunals for considering the requested intervention to be premature. To this it must be added the infringement proceedings initiated last summer against five EU Member States (namely Austria, the Netherlands, Romania, Slovakia and Sweden) requesting them to terminate their intra-EU BITs. See European Commission - Press Release IP/15/5198, I8th June 2015 ('Commission asks Member States to terminate their intra-EU bilateral investment treaties').

I6 See Micula $v$ Romania, ICSID Case No ARB/05/20, Award of II December 20I3. Two Swedish citizens made an investment in Romania prior to its EU accession benefitting from a state aid scheme which was later repealed for being incompatible with EU law. The ICSID arbitral tribunal considered that Romania has infringed the legitimate expectations of the Swedish investors as protected under the Swedish-Romanian BIT.

${ }_{17}$ See European Commission, Decision (EU) 2015/1470 of 30 March 2015 on State aid SA.38517 (2014/C) (ex 2014/NN). For an instructive overview, see P. Ortolani, 'Intra-EU Arbitral Awards vis-à-vis Article Io7 TFEU: State Aid Law as a Limit to Compliance', 6 Journal of International Dispute Settlement (2015) II8-I35. The decision of the European Commission preventing Romania from compliance has been challenged by the award creditors and the case is now pending before the General Court of the EU (Case T-646/I4), whereas the enforcement procedure is also pending before the Bucharest Court of Appeals (Curtea de Apel București, Case No 15755/3/2014). 
and how to conceive their enforcement before the courts of EU Member States. Part III summarizes the main findings and draws some conclusions.

\section{(B) FROM WASHINGTON TO STRASBOURG}

Convergences between human rights and international investment protection have been receiving increased attention since international investment agreements were famously described by a prominent scholar as 'human rights treat[ies] for a special interest group', namely foreign investors ${ }^{18}$. In fact, recent cases, such as Yukos v Russia ${ }^{19}$ and Bozbey v Turkmenistan ${ }^{20}$, provide strong evidence that these treaty regimes may operate concurrently in the same direction ${ }^{2 \mathrm{I}}$ by protecting similar rights $^{22}$. Although both the ECHR and the ICSID Convention contain provisions on lis pendens purported to avoid parallel proceedings ${ }^{23}$, it remains still possible for claims based on the same facts to

I8 J. Álvarez, 'Critical Theory and the North American Free Trade Agreement's Chapter Eleven', 28 University of Miami Inter-American Law Review (1997) 303-312, at 308.

19 See ECtHR, OAO Neftyanaya Kompaniya Yukos v Russia [2012]. For an overview, see E. De Brabandere, 'Complementarity or Conflict? Contrasting the Yukos-case before the European Court of Human Rights and Investment Tribunals', 30(2) ICSID Review (2015) 345-355.

${ }_{20}$ See Bozbey $v$ Turkmenistan, Merits, UN Doc CCPR/C/I00/D/I530/2006, (20II) I8 IHRR 4I4, IHRL 3786 (UNHRC 20I0), 27th October 20I0, Human Rights Committee [UNHRC].

${ }^{21}$ See A. Wythes, 'Investor-State Arbitrations: Can the 'Fair and Equitable Treatment' Clause Consider International Human Rights Obligations?', 23 Leiden Journal of International Law (20I0) 24I-256; J. D. Fry, 'International Human Rights Law in Investment Arbitration Evidence of International Law's Unity', is Duke Journal of Comparative and International Law (2007) 77-150; M. Jacob, 'Faith Betrayed: International Investment Law and Human Rights', in R. Hofmann and C. Tams (eds), International Investment Law and Its Others (Nomos, Baden-Baden, 20I2); M. Jacob, 'International Investment Agreements and Human Rights', INEF Research Paper Series on Human Rights, Corporate Responsibility and Sustainable Development 03/2010 (Institute for Development and Peace, University of Duisburg/Essen, Duisburg, 2010); N. Klein, 'Human Rights and International Investment Law: Investment Protection as Human Right?', 4 Goettingen Journal of International Law (2012) 199-215; E. De Brabandere, 'Human Rights Considerations in International Investment Arbitration', in M. Fitzmaurice and P. Merkouris (eds), The Interpretation and Application of the European Convention of Human Rights: Legal and Practical Implications (Martinus Nijhoff, Leiden,20I2) I83-215; S. L. Karamanian, 'The Place of Human Rights in Investor-State Arbitration', I7(2) Lewis and Clark Law Review (2013) 423-447; T. G. Nelson, 'Human Rights Law and BIT Protection: Areas of Convergence', The Journal of World Investment and Trade (20II) 27-47; B. Simma and T. Kill, 'Harmonizing Investment Protection and International Human Rights: First Steps Towards a Methodology', in C. Binder (ed), International Investment Law for the 2Ist Century: Essays in Honour of Christoph Schreuer (OUP, Oxford, 2009) 678707; U. Kriebaum and C. Schreuer, 'The Concept of Property in Human Rights Law and International Investment Law', in S. Breitenmoser (ed), Human Rights, Democracy and the Rule of Law. Liber Amicorum Luzius Wildbaber (Dike, Zürich, 2007) 743-762.

${ }_{22}$ This finding should not be misunderstood as suggesting that arbitral tribunals adjudicate fundamental rights claims of the aggrieved investors, which fell beyond their jurisdiction. See S. L. KARAMANIAN, supra n. 2I, at 432, 437 (noting that '[a]n investor-state tribunal ... has jurisdiction to resolve only the disputes arising under the applicable [international investment agreement] ... They do not expressly authorize the tribunals to resolve human rights claims'. Even though 'the investor could rely on a jus cogens norm to support its claim that the host state breached the investment treaty ... the tribunal could not resolve the merits of the human rights violation ... as such a determination would be beyond its jurisdiction').

23 On the one hand, Article 26 of the ICSID Convention provides that '[c]onsent of the parties to arbitration under this Convention shall, unless otherwise stated, be deemed consent to such arbitration to the exclusion of any other remedy'. On the other hand, Article $35, \$ 2$, b) of the ECHR similarly states that ' $[\mathrm{t}]$ he $[\mathrm{ECtHR}]$ shall not deal with any application ... that is substantially the same as a matter that has already been examined by the Court or has already been submitted to another procedure of international investigation or settlement and contains no relevant new information'. 
be adjudicated by the ECtHR, on the one hand, and by investment arbitral tribunals, on the other, as long as the triple identity test (parties, facts and action) is strictly applied ${ }^{24}$.

Relevant as this interaction between both treaty regimes may be, this is not the perspective taken here when suggesting a functional convergence to operate between the ECHR and the ICSID Convention. Unlike as in the kind of interaction mentioned above, the interplay argued here relies on both treaties operating sequentially instead of concurrently. And, unlike as in that kind of interaction, the mutual supportive relationship suggested here does not emerge because of different provisions granting substantive protection under the same factual circumstances, but instead relies on the outcomes of one treaty regime being afforded procedural protection under another.

As noted above, the ECtHR has confirmed that States may breach their human rights obligations by unduly denying enforcement to arbitral awards. In particular, the relevant framework for determining such a breach is provided by the close interplay of the right to property, as guaranteed under Article I of Protocol No I of the ECHR, and the right of access to a court, as guaranteed under Article 6(I) of the ECHR 25 .

On the one hand, Article I of Protocol No I of the ECHR provides for the right to peaceful enjoyment of possessions ${ }^{26}$. For arbitral awards to qualify as possessions protected under this provision, the ECtHR requires them to have 'given rise to a debt in [the applicant's] favour that [is] sufficiently established to be enforceable ${ }^{27}$. This can be considered to be the case when the award is

24 See ECtHR, OAO Neftyanaya Kompaniya Yukos $v$ Russia [20II], paras 519-526 (where the ECtHR confirmed the admissibility of the claim arguing that despite certain similarities in the subject-matters of the present case and of the [investment] arbitration proceedings, the claimants in those [investment] arbitration proceedings are the applicant company's shareholders acting as investors, and not the applicant company itself, as it was in the case brought before the ECtHR). See also Limited Liability Company Amto v Ukraine, Final Award, 26 Mar 2008 (SCC Case No. 080/2005), para 7I (similarly arguing that " $\mathrm{t}$ ] his is a case of an international tribunal and a supra-national court having concurrent jurisdiction over a dispute arising out of similar facts. However, the parties and the causes of action are different in these two proceedings. With regard to the parties, [the applicant before the ECtHR] is not a party to the present arbitration and [the applicant in this proceeding] is not a party to the ECHR proceedings. With respect to the causes of action, the present arbitration is based on alleged breaches of the [Energy Charter Treaty], while proceedings before the ECHR are based on Article 6(I) of the European Convention and its Protocol No. I, Article I. These circumstances are sufficient to disqualify the ... lis pendens objection').

${ }_{25}$ For an overview, see K. Timár, 'Europäische Menschenrechtskovention und internationale Schiedsgerichtsbarkeit', in M. Ahrens, V. Lipp and I. Varga (eds), Grundrechte im Zivilprozess (ELTE Eötvös Kiadó, Budapest, 20I5); M. V. Benedetti, 'Human rights as a litigation tool in international arbitration: reflecting on the ECHR experience', 3I(4) Arbitration international (2015) I-29; L. Guglya, 'International Review of Decisions Concerning Recognition and Enforcement of Foreign Arbitral Awards: A Threat to the Sovereignty of the States or an Overestimated Hazard (so far)? (With Emphasis on the Developments within the International Investment Arbitration Setting)', 2 Czech Yearbook of International Law (20II), 93-I2I; G. E. Kodek, 'Verfassung und Grundrechte', in C. Liebscher, P. Oberhammer and W. H Rechberger (eds), Schiedsverfabrensrecht (Vienna: Springer, 2012); Klára Drličková, 'Application of the Article 6(I) of the ECHR in International Commercial Arbitration', in Az állam és jog alapvetô értékei II (Széchenyi István Egyetem Állam - és Jogtudományi Doktori Iskola, Győr, 20I0) 250-264.

26 'Every natural or legal person is entitled to the peaceful enjoyment of his possessions. No one shall be deprived of his possessions except in the public interest and subject to the conditions provided for by law and by the general principles of international law. The preceding provisions shall not, however, in any way impair the right of a state to enforce such laws at it deems necessary to control the use of property in accordance with the general interest or to secure the payment of taxes or other contributions or penalties'.

27 ECtHR, Stran Greek Refineries and Stratis Andreadis $v$ Greece [1994], para 59. The EctHR has since repeatedly applied the same criterion in Sedelmayer v Germany [2009], para I (observing that the arbitral award at stake had given rise 
final and binding according to the relevant legislation and determines the specific amount of liability of the debtor against whom it has been rendered ${ }^{28}$. The interference on the right may then arise as long as it appears impossible for the award creditor to secure enforcement $t^{29}$, or this is only partially granted ${ }^{30}$, be it due to judicial decision ${ }^{31}$ or legislative acts $^{32}$.

Moreover, it should be noted that the protection granted under Article I of Protocol No I operates irrespective of the domestic, foreign or international nature of the arbitral award ${ }^{33}$. Nor is it conditioned upon the nationality of the parties to the underlying arbitration ${ }^{34}$, their public or private nature ${ }^{35}$, or the means by which they came into possession of the award ${ }^{36}$. Finally, it also appears to be

to a debt in the applicant's favour that was sufficiently established to be enforceable. Therefore, the applicant had a "possession" for the purposes of Article I of Protocol No. I'); Regent Company v Ukraine [2008], para 63 (arguing that 'a "claim" can only constitute a "possession" within the meaning of Article I of Protocol No. I if it is sufficiently established to be enforceable ... domestic court's judicial decisions acknowledging that the applicant company was the creditor in the proceedings as to enforcement of the arbitration award ...mean that it had an enforceable claim which constituted a "possession" within the meaning of Article I of Protocol No. I'); Kin-Stib o $\mathcal{N}$ Majkić v Serbia [2010], para 83 (stating that 'it is the State's responsibility to make use of all available legal means at its disposal in order to enforce a binding arbitration award providing it contains a sufficiently established claim amounting to a possession').

${ }_{28}$ See ECtHR, Stran Greek Refineries and Stratis Andreadis $v$ Greece [1994], paras 6I-62 (where the ECtHR stated that an arbitral award rendered against Greece that 'clearly recognized the State's liability up to a maximum of specified amounts' and 'was final and binding ... conferred on the applicants a right in the sums awarded').

29 The property right may not only be interfered by simply refusing enforcement, but also where the forum State is found not to have taken 'the necessary measures to fully enforce the arbitration award', as stated in Kin-Stib $\mathcal{F}$ Majkić $v$ Serbia [2010], where the ECtHR held that States are required 'to make use of all available legal means at its disposal in order to enforce a binding arbitration award providing it contains a sufficiently established claim amounting to a possession' and 'make sure that the execution of such an award is carried out without undue delay and that the overall system is effective both in law and in practice' (para 83).

30 See ECtHR, Kin-Stib o Majkić v Serbia [2010], where Serbia was held to have partially expropriated an arbitral award by granting only partial enforcement.

3I See ECtHR, Sedelmayer $v$ Germany [2009], para I (where the ECtHR sought to ascertain whether the German courts struck a fair balance between the property right of the award creditor and the rules on sovereign immunity from execution

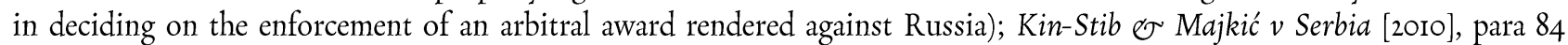
(where the ECtHR scrutinize the decision of a Serbian court to stay the enforcement proceedings of an arbitral award before the latter being fully executed).

32 See ECtHR, Stran Greek Refineries and Stratis Andreadis $v$ Greece [1994], where the judicial denial of enforcement was indirectly due to a domestic law enacted in order declare terminate the contracts concluded by the State during the dictatorship period between 1967 and 1974. Having been issued on the basis of an arbitral clause contained in one of those contracts, the award at stake was rendered unenforceable. See also Kin-Stib ơ Majkić v Serbia [2010], para 84 (where the ECtHR, whilst focusing its scrutiny on a judicial decision to stay the enforcement proceeding after imposing fines on the award debtors for partially securing the payment of the sum awarded, pointed out that 'it would appear that there were no attempts to fully enforce the award thereafter, the apparent reason for this being that, since the debtors themselves were corporate entities, there were simply no other legal means available whereby their compliance could be secured' [emphasis added]).

33 While the case Stran Greek Refineries and Stratis Andreadis $v$ Greece [1994] involved a Greek domestic award, those at stake in the cases Regent Company v Ukraine [2008], Sedelmayer v Germany [2009] and Kin-Stib o $r$ Majkić v Serbia [2010] involved international or foreign-related elements.

34 It appears to be irrelevant whether the award creditors are nationals of State parties to the ECHR or not. See ECtHR, Kin-Stib o Majkić $v$ Serbia [2010], where the award at stake was rendered in favour of a Congolese company.

35 The award debtor was a State in Stran Greek Refineries and Stratis Andreadis $v$ Greece [1994] and Sedelmayer $v$ Germany [2009]; and a State-owned company in Regent Company $v$ Ukraine [2008] and Kin-Stib $\mathcal{F}$ Majkić $v$ Serbia [20IO].

36 See ECtHR, Regent Company v Ukraine [2008], where the appellant, which was not involved in the underlying arbitration, purchased the award from the winning party. 
irrelevant the fact that the role of the State before whose courts the arbitral award has been brought is limited to a mere enforcement forum, without any further connection to the underlying arbitration ${ }^{37}$.

Once an interference on the property rights of the award creditors has been established, a proportionality test is still to be applied for assessing whether such an interference may be considered unlawful and hence amount to a violation of Article I of Protocol No I of the ECHR. This test requires the property right of the award creditor to be weighed against the public interest that may be invoked by the forum State in order to justify why the enforcement has been refused or only partially granted. The sole general interest so far admitted as imposing limitations on the enforcement of awards relates to the protection of sovereign immunity from execution ${ }^{3}$. It should be noted, however, that some scholars have suggested that this proportionality test would not be applied when the applicant is not a national of the forum State, the ultimate reason for this being the disparate treatment accorded to property rights of foreigners under the ECHR 39.

Besides being equated to property rights which may be expropriated by denying enforcement, arbitral awards have been granted further protection under Article 6(I) of the ECHR. The right of access to court enshrined therein has been considered to comprise the right to enforcement of judicial decision $s^{40}$, which was later extended by analogy to arbitral award $s^{4}$. Had the forum State failed to

37 See ECtHR, Sedelmayer $v$ Germany [2009], where the award at stake was rendered against the Russian State, Germany being neither a party to the underlying arbitration, nor the country in which the latter was conducted.

38 See ECtHR, Sedelmayer $v$ Germany [2009], para I stating that 'the grant of sovereign immunity to a State in civil proceedings pursues the legitimate aim of complying with international law to promote comity and good relations between States'; and concluding that the German courts struck a fair balance between the right of the applicant and the public interest by refusing to execute Russian assets protected by sovereign immunity). Besides, the ECtHR has clearly rejected arguments premised on the existence of vague difficulties, as those dismissed in Kin-Stib o $\mathcal{O}$ Majkić v Serbia [2010], where the Serbian authorities alleged to have done 'everything in their power to fully enforce the arbitration award'. Even the claimed political interest in eliminating the vestiges of the Greek dictatorship was rejected as justification in Stran Greek Refineries and Stratis Andreadis $v$ Greece [1994]. Nor has the ECtHT admitted as excuse the insolvency of the State-owned company against whom the award was rendered in Regent Company $v$ Ukraine [2008].

39 See S. Konrad and M. Birch, 'Non-Enforcement of Arbitral Awards: Only A Pyrrhic Victory?', 5(I) Transnational Dispute Management (2010) I-9, at 4 (noting that, unlike in the case of Stran Greek Refineries and Stratis Andreadis $v$ Greece [1994], no proportionality test seems to be applied by the ECtHT in the case of Regent Company $v$ Ukraine [2010]). This difference is suggested to be due to the disparate treatment accorded to nationals and non-nationals as regards the protection of property rights under the ECHR. See ECtHR, Lithgow and Others $v$ United Kingdom [1986] and James and Others $v$ United Kingdom [1986], where the ECtHT incorporated this disparity of treatment as shaped in international law. See E. Borchard, 'Minimum Standard of the Treatment of Aliens', 38 (4) Michigan Law Review (1940) 445-46r; L. Sohn and R. Baxter, 'Responsibility of States for Injuries to the Economic Interests of Aliens', 55(3) American Journal of International Law (196I) 547-585. However, against the hypothesis suggested, it should be noted that the proportionality test seems to have been also disregarded in Kin-Stib e $\mathcal{O}$ Majkić $v$ Serbia [20IO], where the applicants were nationals of the respondent State.

40 As famously stated by the ECtHR in Hornsby $v$ Greece [1997], para 40, Article 6(I) of the ECHR 'secures to everyone the right to have any claim relating to his civil rights and obligations brought before a court or tribunal; in this way it embodies the "right to a court", of which the right of access, that is the right to institute proceedings before courts in civil matters, constitutes one aspect ... However, that right would be illusory if a Contracting State's domestic legal system allowed a final, binding judicial decision to remain inoperative to the detriment of one party. It would be inconceivable that [Article 6(I)] should describe in detail procedural guarantees afforded to litigants -proceedings that are fair, public and expeditious- without protecting the implementation of judicial decisions'. See also ECtHR, Apostol $v$ Georgia [2006], para 56 (stating that the right to access to a court likewise protects the right of access to enforcement proceedings').

${ }_{4 \mathrm{I}}$ See ECtHR, Regent Company $v$ Ukraine [2008], para 54. The decision to extend the right to enforcement of judicial decisions to arbitral awards relied ultimately upon the findings of Lithgow and Others v United Kingdom [1986], para 20I, whereby arbitral tribunals had been equated to 'tribunal[s] established by law' in the sense of Article 6(I) of the ECHR, 
grant full enforcement, a concurrent violation of both Article 6(I) of the ECHR and Article I of Protocol No I of the ECHR may then be established ${ }^{42}$. Whether the failure of the forum State to enforce the arbitral award is to be scrutinized concurrently or separately under both provisions remains largely unclear from the case-law of the ECtHR ${ }^{43}$.

Be that as it may, it seems likely that the rationale applied by the ECtHR could be extended as to afford equivalent protection to ICSID awards seeking enforcement. The requirements appear to be met since Article 53(I) of the ICSID Convention provides that ' $[\mathrm{t}]$ he award shall be binding on the parties and shall not be subject to any appeal', whilst Article 54(I) mandates every State party to 'recognize [the] award ... as binding and enforce the pecuniary obligations imposed by that award ... as it were a final judgment of a court in that State'44. Once validly rendered, ICSID awards may be properly considered to have 'given rise to a debt in [the applicant's] favour that [is] sufficiently established to be enforceable'45, as literally required by the ECtHR. This appears to be all the more so

whose wording 'may comprise a body set up to determine a limited number of specific issues, provided always that it offers the appropriate guarantees'. See also ECtHR, Transado-Transportes Fluviais do Sado v Portugal [2003], para 2; Suda v Czech Republic [2010], para 48; Kolgu v Turkey [2013], para 40.

42 Both provisions may be concurrently violated since, as the ECtHR has repeatedly stated, 'one and the same fact may fall foul of more than one provision of the Convention and Protocols' (see İletmiş $v$ Turkey [2005], para 50; Vendittelli $v$ Italy [1994], para 34; Poiss v Austria [1987], para 66; Erkner and Hofauer v Austria [1987], para 76). Indeed, both provisions were deemed to have been concurrently violated in Regent Company $v$ Ukraine (2008), but not so in Kin-Stib o $\mathcal{N}$ Majkić $v$ Serbia [20IO], where the ECtHR, once the violation of Article I of Protocol No. I of the ECHR was established, declared not to be necessary 'to examine separately the same issue under Article $6 \$$ I of the Convention' (para 86). Moreover, in Sedelmayer $v$ Germany [2009] the ECtHR did not even think it worth considering whether a violation of Article 6 (I) of the ECHR had occurred.

43 See A. Jakšic', 'The Execution of Final Judgments and Vested Rights', 2 (3) Russian Law Journal (20I4) 62-79, at 66-67 (pointing out that 'in some cases the [ECtHR] did not find it necessary to examine separately the issue of whether the failure to enforce a final judicial decision also violated Art. 6(I) of the [ECtHR]. In other cases the [ECtHR] took quite the opposite view. However, the [ECtHR] has until now determined no firm criteria which could serve as guidelines for both the theory and the practice as to the cases in which the non-enforcement of a final judicial decision would be examined as an issue pertaining to the scope and ambit of both norms allegedly violated. Quite to the contrary, the practice of the [ECtHR] is ambiguous when not also arbitrary').

44 Article 54(2) of the ICSID Convention only requires a party seeking enforcement to furnish to [the] competent court ... a copy of the award certified by the Secretary-General' of the ICSID Administrative Council. Indeed, ICSID awards have been featured as being 'enforceable within the Contracting States with no resistance to the enforcement possible'. See Albert Jan van den Berg, 'Some Recent Problems in the Practice of Enforcement under the New York and ICSID Conventions', 2 ICSID Review (1987) 439-56, at 439. Indeed, Article 54(I) of the ICSID Convention has even been suggested to perform a direct effect comparable to that accorded to EU law by the Van Gend en Loos decision of the ECJ. See A. Nollkaemper, "The Duality of Direct Effect of International Law', 25 (I) European Journal of International Law (2014) IO5-I25, at I23 (note II2).

45 Yet it has been suggested otherwise. See Y. Kryvoi, 'Kin-Stib \& Majkić v. Serbia (Eur. Ct. H.R.), Introductory Note', 49(4) International Legal Materials (2010) II8I-II94, at II83. The argument is there made that, in order for awards to be equated to property rights which may be expropriated by denying enforcement, the failure to enforce them should deprive award creditors from the economic benefit of their property. Since ICSID awards can be enforced in any State party to the ICSID Convention, the author concludes that 'their non-enforcement in one jurisdiction may not completely deprive the enforcing party of its economic benefit', unless in those 'situations where it is practically impossible to enforce the ICSID award in another jurisdiction (i.e., no assets abroad)'. Reasonable as this argument may appear to be, it seems unfeasible to impose on the ECtHR the burden of assessing in each case the possibilities for the award creditor to attach assets worldwide in the jurisdiction of the I5I States (!) that have so far ratified the ICSID Convention. 
given the deference accorded to ICSID awards at the enforcement stage by the domestic courts of several countries being State parties to both the EU and the ECHR ${ }^{46}$.

There is a caveat, however, to this approach. It should be noted that the relationship between arbitral awards and the ECHR may also operate in the opposite direction. In particular, Article 6(I) of the ECHR may be also interpreted as imposing limitations to the recognition and enforcement of arbitral awards. So has it been construed by the ECtHR, for instance, in order to impose on the courts of State parties to the ECHR a duty to ascertain, before granting recognition and enforcement to foreign court decisions, whether the underlying proceedings fulfilled the guarantees of Article 6 of the ECHR ${ }^{47}$. Since arbitral awards have been equated to court decisions within the scope of the right to enforcement under Article 6(I), nothing speaks against the possibility of this provision being operated as preventing their enforcement or imposing a similar previous control ${ }^{48}$.

46 A handful of examples of judicial practice may be invoked here as providing strong evidence of the existing consensus on the automatic enforceability of ICSID awards in the domestic legal order of a significant range of State Parties to both the EU and the ECHR. See, for the case of Germany, Frankfurt Court of Appeal (OLG Frankfurt am Main), Decision ('Beschluss') of $20^{\text {th }}$ November 20I2, Az. I8 W 59/12, paras 27-28 (stating that, unlike in the case of ordinary foreign awards governed by the New York Convention which have to be submitted to a judicial procedure for being confirmed as enforceable before being properly executed [Vollstreckbarkeitserklärung], ICSID awards can be directly submitted to a proper judicial enforcement procedure [Zwangsvollstreckung]'); for the case of France, Cour de cassation, Decision ('Arrêt') of $\mathrm{Ir}^{\text {th }}$ June 199I (arguing that Articles 53 and 54 of the ICSID Convention have established an autonomous and simplified system for the enforcement of awards which excludes the application of French domestic procedural law); for the case of the United Kingdom, Court of Appeal (Civil Division), Decision of $9^{\text {th }}$ September 2005, [2005] EWCA Civ III6, para 38 (stating that '[i]n the case of an ICSID arbitration, no recourse to the English court is currently possible under the Arbitration Act 1996 ' and further noting that ' $[t]$ he ICSID scheme also differs in having its own enforcement mechanism, so that the New York Convention is inapplicable'); for the case of Spain, Juzgado de Primera Instancia No. Ior de Madrid, Decision ('Auto') of $4^{\text {th }}$ July 20I3, Victor Pey Casado $v$ Republic of Chile (stating that ICSID awards can be directly enforced without being previously granted exequatur).

47 See ECtHR, Pellegrini v Italy [200I], para 40 and 47 (where Italy was held in breach of Article 6 of the ECHR as long as its courts neglected their duty to ascertain, before granting enforcement to a Vatican judgment, whether the underlying proceedings conducted under Canon law fulfilled the guarantees of Article 6 of the ECHR). See also ECtHR, Drozd and Janousek $v$ France and Spain [1992], para IIo (where the ECtHR held that the courts of the States parties to the ECHR, whilst not being required to verify whether the underlying proceedings were compatible 'with all the requirements of Article 6, are obliged to refuse recognition and enforcement of foreign court decisions in the case 'of a flagrant denial of justice'). For an overview on the operation of Article 6 of the ECHR against recognition and enforcement of foreign court decisions, see D. Spielmann, 'Recognition and Enforcement of Foreign Judicial Decisions. Requirements under the European Convention on Human Rights. An Overview', I(I) Cyprus Human Rights Law Review (2012) 4-24; J. Fawcett, 'The Impact of Article 6(I) of the ECHR on Private International Law', 56 International and Comparative Law Quarterly (2007) I48; P. Kinsch, 'The Impact of Human Rights on the Application of Foreign Law and on the Recognition of Foreign Judgments - A Survey of the Cases Decided by the European Court of Human Rights Institutions', in Talia Einhorn and K. Siehr (eds), Intercontinental Cooperation Through Private International Law. Essays in Memory of Peter E. Nygh (TMC Asser Press, The Hague, 2004) 197-228; Steven Stuij, 'Some Aspects of the Application and Ascertainment of Foreign Law in the Light of Article 6 of the ECHR', in C. Paulussen, T. Takács, V. Lazić, B. Van Rompuy (eds), Fundamental Rights in International and European Law: Public and Private Law Perspectives (TMC Asser Press, The Hague, 2016) I85-209.

${ }_{48}$ Were the arbitration proceedings hypothetically considered to have been conducted in breach of Article 6 of the ECHR, domestic courts may be then required by the latter not to enforce the resulting arbitral award. Some scholars appear to endorse this view. See E. Kleiman, "The SNF v. International Chamber of Commerce Case and the Obligation to Conduct Arbitration Proceedings with "Expected Dispatch"', in D. Bray and H. L. Bray (eds), International Arbitration and Public Policy (Juris, New York, 2015) 49-92, at 80 (arguing that if a national court were to misapply the ECHR, i.e. by enforcing awards that contravene the ECHR and thus give effect to a violation of the ECHR in their legal system, a claim to the European Court of Human Rights against that state may succeed'); A. Pinna, 'The Trials and Tribulations of the Court of Arbitration for Sport. Contribution to the Study of the Arbitration of Disputes concerning Disciplinary Sanctions', I-2 
Yet the ambiguous case-law of the ECtHR in the field of arbitration suggests this analogy be considered with caution. To begin with, the extent to which Article 6(I) of the ECHR is considered mandatory depends on the distinction between voluntary arbitration and compulsory arbitration, the latter being required to offer the guarantees set forth in this provision ${ }^{49}$. Though ambiguity arises, in turn, as regards voluntary arbitration. First, national courts have arguably not been required to exhaustively ensure that arbitral proceedings are conducted in full conformity with Article 6(I) of the ECHR $^{50}$. Having said that, State responsibility is not entirely excluded inasmuch as arbitral awards have to be recognized by national courts and be given executory effect by them ${ }^{51}$. Finally, the case-law of the ECtHR, as well as the judicial practice of certain State parties to the ECHR, suggests that Article 6 should be construed as conferring on the parties a right to challenge rendered arbitral awards before national courts, even though such a right, as others under Article 6, could be waived by their mutual consent $t^{52}$.

International Sports Law Journal (2005) 8-18, at $\mathrm{I} 6$ (suggesting that the rationale applied by the ECtHR in Pellegrini $v$ Italy may be extended to arbitral awards); A. J. Bělohlávek, 'Arbitration from Perspective of Right to Legal Protection and Right to Court Proceedings (the Right to Have One's Case Dealt with by a Court): Significance of Autonomy and Scope of Right to Fair Trial', Czech and Central European Yearbook of Arbitration (201I) 47-70, at 62, n. $3 \mathrm{I}$ (noting that 'it has an impact not only at the level of state responsibility in relation to arbitration conducted in its own territory, but also in relation to arbitration conducted abroad. The latter aspect is manifested, in particular, in the recognition and enforcement of foreign arbitral awards'); C. Rood, Private International Law, Art and Cultural Heritage (Edward Elgar, Cheltenham/Northampton, 2015) at 155 (arguing that 'States do not assume any direct responsibility under human rights instruments for the conduct of arbitral proceedings; they assume subsidiary responsibility for the right to appeal, or to oppose the recognition and enforcement of awards that violate international private rights or procedural minima').

49 See ECtHR, Kolgu v Turkey [2013], para 40; Suda v Czecb Republic [2010], para 49. See also EComHR, Rychetsky $v$ Switzerland [1987]; Bramelid $\mathfrak{O}$ Malmström v Sweden [1983].

so In Nordstrom-Janzon and Nordstrom-Lebtinen $v$ The Netherlands [1996], the now disappeared European Commission of Human Rights ('EComHR') argued that 'the grounds on which arbitral awards may be challenged before national courts differ among the Contracting States and considers that it cannot be required under the Convention that national courts must ensure that arbitral proceedings have been in conformity with Article 6 [of the ECHR]. In some respects - in particular as regards publicity - it is clear that arbitral proceedings are often not even intended to be in conformity with Article 6 [of the ECHR], and the arbitration agreement entails a renunciation of the full application of that Article. The Commission therefore considers that an arbitral award does not necessarily bave to be quashed because the parties bave not enjoyed all the guarantees of Article 6 [of the ECHR], but each Contracting State may in principle decide itself on which grounds an arbitral award should be quashed' (emphasis added). This argument has been further followed by the ECtHR in Osmo Suovaniemi and Others $v$ Finland [1999], arguing that 'the Contracting States enjoy considerable discretion in regulating the question on which grounds an arbitral award should be quashed, since the quashing of an already rendered award will often mean that a long and costly arbitral procedure will become useless and that considerable work and expense must be invested in new proceedings' (emphasis added).

5I In Rychetsky $v$ Switzerland [1987], the EComHR argued that 'the State cannot be held responsible for the arbitrators' actions unless, and only insofar as, the national courts were required to intervene'. In Jakob BOSS Söbne KG v Germany [199I], the EComHR further stated that the decision to submit a dispute to private arbitration 'does not mean, however, that the respondent State's responsibility is completely excluded ... as the arbitration award had to be recognised by the German courts and be given executory effect by them. The courts thereby exercised a certain control and guarantee as to the fairness and correctness of the arbitration proceedings which they considered to have been carried out in conformity with fundamental rights and in particular with the right of the applicant company to be heard' (emphasis added).

${ }_{52}$ See ECtHR, Transado-Transportes Fluviais do Sado v Portugal [2003], para 2 (arguing that it is true that no appeal lay against the arbitration tribunal's decision, but it was the applicant company itself, in agreement with the APS, which chose to insert such a clause in the concession contract. There is nothing to prevent an applicant from waiving certain rights, provided that such a waiver is, as in the instant case, lawful and unequivocal'). See also Swiss Federal Supreme Court, Decision of $4^{\text {th }}$ January 20I2, Case No. 4A_238/20II, para 3.2 (assuming that Article 6 of the ECHR confers a right to challenge arbitral awards before national courts in order to state that the waiver of such a right is compatible with this 
As for the case under discussion, suffice it here to note that arbitration conducted under the ICSID Convention may hardly qualify as compulsory $y^{53}$. Yet the most crucial issue for determining its legal status under the ECtHR appears to rely rather on the fact that arbitral proceedings conducted within its legal framework are considered to be territorially delocalized and hence hermetically isolated from any domestic legal order ${ }^{54}$. Should the ICSID Convention be thus conceived as a treatybased mechanism for purely international arbitration, then its legal status is to be further assessed against the criteria laid down by the case-law of the ECtHR on human rights obligations imposed on the States as treaty-makers5.

Insofar as relevant here, the rationale arising from this settled case-law can essentially be summarized in the statement that, under Article I of the ECHR ${ }^{56}$, 'the Member States are responsible for all acts and omissions of their domestic organs allegedly violating the Convention regardless of whether the act or omission in question is a consequence of domestic law or regulations or of the

provision by arguing that '[s]ans doute la renonciation au recours implique-t-elle l'impossibilité pour la partie qui a succombé de faire constater par le Tribunal fédéral que la sentence attaquée a été rendue en violation des garanties procédurales fondamentales prévues par cette norme conventionnelle [Article 6 of the ECHR]. Toutefois, ni la lettre ni l'esprit de celle-ci n'empêchent une personne de renoncer à de telles garanties de son plein gré, pour autant que pareille renonciation ne soit pas équivoque et ne se heurte à aucun intérêt public important'). See also Court of Appeal of England and Wales, Sukuman Ltd v Commonwealth Secretariat [2007] EWCA Civ 243, para 25 (stating that ' $[$ t] here can be no doubt that parties to a commercial contract, including a public authority, can enter into an agreement to refer all disputes to arbitration thereby entitling them as of right not to have such disputes resolved "at a public hearing by a tribunal established by law", without there being any failure to comply with Article 6 [of the ECHR]').

53 Account should be taken in any case of the international investment agreement upon which the ICSID arbitral tribunal had based its jurisdiction. Most of such agreements usually contain clauses by which States express their consent to arbitration and make a standing offer to arbitrate, which foreign investors accept by submitting a claim. These clauses are frequently designed as fork-in-the-road provisions, by which foreign investors are required to irrevocably choose between international arbitration or litigation before domestic courts, the choice for one option being final to the exclusion of the other.

54 See L. Reed, J. Paulsson and N. Blackaby (eds), Guide to ICSID Arbitration (Kluwer Law International, Alphen aan den Rijn, 20II) at I4 (explaining that ' $[$ t he ICSID process is entirely self-contained and hence delocalized').

55 See EurCHR, M o Co $v$ Germany [1990]; ECtHR, Matthews $v$ United Kingdom [1999]; Waite and Kennedy $v$ Germany [1999]; Bosphorus Hava Yollari $v$ Ireland [2005]; Bebrami and Bebrami v France and Saramati $v$ France, Germany and Norway [2007]; Al-Jedda $v$ The United Kingdom [20II]; Nada $v$ Switzerland [2012]. A general assessment of this case law is beyond the scope of this paper. For an overview, see C. Janik, Die Bindung internationaler Organisationen an internationale Menschenrechtsstandards (Tübingen: Mohr, 20I2), at I5I et seq; C. Ryngaert, 'The European Court of Human Rights' Approach to the Responsibility of Member States in Connection with Acts of International Organizations', 6o(4) International and Comparative Law Quarterly (20II) 997-Ior6; T. Lock, 'Beyond Bosphorus: the European Court of Human Rights' Case law on the Responsibility of Member States of International Organisations under the European Convention on Human Rights' (2010) Human Rights Law Review 529-545; C. Tomuschat, 'The European Court of Human Rights and the United Nations', in A. Føllesdal, Birgit Peters and Geir Ulfstein (eds), Constituting Europe: The European Court of Human Rights in a National, European and Global Context (CUP, Cambridge, 2013) 334-388.

${ }_{56}$ Article I of the ECHR provides that ' $\mathrm{t}$ ] he High Contracting Parties shall secure to everyone within their jurisdiction the rights and freedoms defined in Section I of this Convention'. See ECtHR, United Communist Party of Turkey and Others $v$ Turkey [1998], para 29 (explaining how Article I of the ECHR demarcates the scope of the Convention ratione personae, materiae and loci ... It makes no distinction as to the type of rule or measure concerned and does not exclude any part of the member States' "jurisdiction" from scrutiny under the Convention. It is, therefore, with respect to their "jurisdiction" as a whole -which is often exercised in the first place through the Constitution- that the States Parties are called on to show compliance with the Convention'). 
necessity to comply with international obligations's7. In particular, the ECtHR has explicitly acknowledged that the domestic enforcement of a decision issued by an international adjudicatory body on which States parties to the ECHR have conferred powers through a treaty is not prevented from amounting to responsibility under the $\mathrm{ECHR}^{58}$.

The same rationale would appear to squarely apply in the case of the ICSID Convention, where its Member States have availed themselves of treaties for the purpose of transferring adjudicatory powers to international arbitral tribunals and committing themselves to enforce the resulting arbitral awards in their national jurisdictions $s^{59}$. In order for State action taken in compliance with such treaty obligations (i.e. enforcement of awards) to be presumed justified under the ECHR, the relevant organization (i.e. the ICSID arbitral system) would be then required 'to protect fundamental rights, as regards both the substantive guarantees offered and the mechanisms controlling their observance, in a manner which can be considered at least equivalent to that for which the [ECHR] provides' ${ }^{\prime 0}$.

Suffice it here to note, however, that a case can hardly be supposed in which an ICSID award may be considered to have been rendered in breach of fundamental rights of foreign investors under the standards of the ECHR, since international investment agreements have been emphatically suggested to provide higher substantive standards of protection than human rights treaties ${ }^{6 \mathrm{I}}$. While such

57 EurCHR, M o C Co v Germany [1990]; ECtHR, Bosphorus Hava Yollari v Ireland [2005], para 153. See also, as the most recent authority, ECtHR, Nada $v$ Switzerland [20I2], para I68 (stating that '[a]ccording to established case-law, a Contracting Party is responsible under Article I of the Convention for all acts and omissions of its organs regardless of whether the act or omission in question was a consequence of domestic law or of the necessity to comply with international legal obligations. Article I makes no distinction as to the type of rule or measure concerned and does not exclude any part of a Contracting Party's "jurisdiction" from scrutiny under the Convention'). Be it noted that the idea of States being held responsible for actions taken in the framework of international organizations is deeply rooted in public international law.

${ }_{58}$ See EurCHR, M o C Co $v$ Germany [1990] (stating that, although the EurCHR is in fact not competent ratione personae to examine proceedings before or decisions of organs of the European Communities, the latter not being a Party to the European Convention on Human Rights ... [t]his does not mean, bowever, that by granting executory power to a judgment of the European Court of Justice the competent German authorities acted quasi as Community organs and are to that extent beyond the scope of control exercised by the Convention organs. Under Article I [of the ECHR] the Member States are responsible for all acts and omissions of their domestic organs allegedly violating the Convention regardless of whether the act or omission in question is a consequence of domestic law or regulations or of the necessity to comply with international obligations' [emphasis added]).

s9 Be it noted that 'treaties' are referred to here in the plural in order to highlight that the ICSID system is premised on two treaties being simultaneously operated. Whereas ICSID arbitral tribunals are conferred jurisdiction by the relevant international investment agreement whose protection standards are claimed to have been breached by the host State, the procedural functioning of these tribunals, as well as the obligation imposed on the States to enforce the resulting arbitral awards, are directly governed by the ICSID Convention.

60 ECtHR, Bosphorus v Ireland [2005], para I55; Behrami and Bebrami $v$ France and Saramati $v$ Germany, France and Norway [2007], para 145. See also EurCHR, M e C Co $v$ Germany [1990] (stating that the transfer of powers to an international organisation is not incompatible with the Convention provided that within that organisation fundamental rights will receive an equivalent protection'). For an overview, see S. Winkler, 'Die Vermutung ,äquivalenten“ Grundrechtsschutzes im Gemeinschaftsrecht nach dem Bosphorus-Urteil des EGMR', 34(22-23) Europäische Grundrechtezeitschrift (2007) 64I-654.

${ }_{6 \mathrm{I}}$ See Spyridon Roussalis $v$ Romania, ICSID Case No. ARB/06/I, Award of $7^{\text {th }}$ December 20II, para 312: (arguing that ' $[t]$ he Tribunal does not exclude the possibility that the international obligations of the Contracting States mentioned at Article Io of the BIT could include obligations deriving from multilateral instruments to which those states are parties, including, possibly, the European Convention of Human Rights and its Additional Protocol No.I. But the issue is moot in the present case and does not require decision by the Tribunal, given the bigher and more specific level of protection offered by the BIT to the investors compared to the more general protections offered to them by the buman rights instruments referred above' 
possibility cannot be hypothetically dismissed, the only objection that can be foreseen from the perspective of the ECHR may lie in the lack of public procedure before the arbitral tribunals ${ }^{62}$.

Be that as it may, the question whether these requirements are met in the framework of the ICSID Convention is to be ultimately ascertained by the ECtHR ${ }^{63}$. Should the standards for protection of fundamental rights be considered equivalent to those of the ECHR, the enforcement of ICSID awards would retain the protection afforded by Article 6(I) of the ECHR ${ }^{64}$.

\section{(C) FROM STRASBOURG TO LUXEMBOURG}

Once explored the supportive relationship being here suggested to operate between the ECHR and the ICSID Convention, the next step requires to ascertain whether, and to what extent, this interaction may be ultimately relevant for the legal status accorded to ICSID awards under EU law.

To begin with, the operation of the ECHR within the framework of EU law is concurrently governed by Article 6 of the Treaty on European Union ('TEU') and Article 52(3) of the Charter of Fundamental Rights ('ChFR') ${ }^{65}$. Whereas the former provides that the fundamental rights guaranteed

[emphasis added]); Quasar de Valores SICAV SA v the Russian Federation, SCC Arbitration, Award of $20^{\text {th }}$ July 20I2, para 22 (stating that human rights conventions establish minimum standards to which all individuals are entitled irrespective of any act of volition on their part, whereas investment-protection treaties contain undertakings which are explicitly designed to induce foreigners to make investments in reliance upon them. It therefore makes sense that the reliability of an instrument of the latter kind should not be diluted by precisely the same notions of "margins of appreciation" that apply to the former', implicitly referring to the like-named doctrine developed under the ECHR [emphasis added]).

62 Public procedure is guaranteed under Article 6(I) of the ECHR. An instructive precedent for the case of an international dispute resolution mechanism being scrutinized from this perspective can be found in Gasparini $\mathrm{v}$ Italy and Belgium [2009]. The ECtHR considered whether the lack of public procedure before the NATO internal commission could amount to a violation of Article 6(I) of the ECHR, this conclusion being finally dismissed for considering the fairness of the procedure not to be affected by the lack of publicity. See also Frankfurt Court of Appeal (OLG Frankfurt am Main), Decision ('Beschluss') of I8 December 2014, 26 Sch 3/13 (Eureko v Slovakia), paras 67-72 (where the German court, being asked to set aside a - non ICSID - investment award, confirmed its competence to ascertain whether the arbitral tribunal had violated the right to a fair hearing [rechtliches Gehör] as guaranteed by the German Constitution, arguing that "[d]er verfassungsrechtlich in Art. I03 Abs. I GG gewährleistete Anspruch auf rechtliches Gehör ist gemäß $₫$ IO42 Abs. I S. 2 ZPO auch im Schiedsverfahren zu beachten. Dabei müssen Schiedsgerichte rechtliches Gehör grundsätzlich im gleichen Umfang wie staatliche Gerichte gewähren ... Bei der Prüfung der Wahrung des rechtlichen Gehörs ist zu beachten, dass das Schiedsgericht Vorbringen der Parteien in den Gründen der Entscheidung nicht notwendig ausdrücklich bescheiden muss; vielmehr liegt eine Verletzung des Gehörsanspruchs nur dann vor, wenn sich aus der vorliegenden Begründung mit hinreichender Deutlichkeit der Schluss aufdrängt, dass das Schiedsgericht den Sachvortrag tatsächlich nicht zur Kenntnis genommen oder doch bei der Entscheidung überhaupt nicht erwogen hat').

${ }_{63}$ The case-law of the ECtHR provides some examples of international mechanisms for dispute resolution being scrutinized under the standards of the ECHR, such as the European Court of Justice in Bosphorus v Ireland [2005] or the NATO internal commission in Gasparini v Italy and Belgium [2009].

${ }^{6}$ See ECtHR, Hornsby $v$ Greece [1997], where Greece was upheld in breach of Article 6(I) of the ECHT for hindering the enforcement of a judgement rendered by the European Court of Justice.

65 A further reference to the ECHR is made in Article 53 of the ChFR, which provides that ' $\mathrm{n}$ ]othing in this Charter shall be interpreted as restricting or adversely affecting human rights and fundamental freedoms as recognized, in their respective fields of application, by Union law and international law and by international agreements to which the Union, the Community or all the Member State are party, including the European Convention of Human Rights and Fundamental Freedoms, and by Member States' constitutions'. Yet this reference has been described as merely redundant. See B. De Witte, 'Article 53 - Level of Protection', in S. Peers, T. Hervey, J. Kenner and A. Ward (eds), The EU Charter of Fundamental Rights (Nomos/C.H.Beck/Hart, Baden-Baden/Munich/Oxford, 20I4) I523-1538, at I527. 
by the ECHR shall constitute general principles of EU law ${ }^{66}$, the latter requires the fundamental rights contained in the ChFR to be given the same meaning and the same scope as those guaranteed by the ECHR ${ }^{67}$.

On the one hand, Article 6(3) of the TFEU has been interpreted by the European Court of Justice ('ECJ') as 'reflect[ing] the settled case-law of the [ECJ] according to which fundamental rights form an integral part of the general principles of law the observance of which the [ECJ] ensures ${ }^{68}$. Article 52(3) of the ChFR, in its turn, has been suggested to operate as what has been called an incorporation or transfer clause ${ }^{69}$, which 'materially incorporates the core norms of the [ECHR] into EU law'70. The normative content being thereby incorporated into the latter encompasses both the ECHR and its Protocols ${ }^{71}$, as well as the case-law of the $\mathrm{ECtHR}^{72}$.

${ }_{66}$ Article 6(3) of the TEU states that '[f]undamental rights, as guaranteed by the European Convention for the Protection of Human Rights and Fundamental Freedoms and as they result from the constitutional traditions common to the Member States, shall constitute general principles of the Union's law.'

${ }_{67}$ Article 52(3) of the ChFR states that 'in so far as this Charter contains rights which correspond to rights guaranteed by the Convention for the Protection of Human Rights and Fundamental Freedoms, the meaning and scope of those rights shall be the same as those laid down by the said Convention. This provision shall not prevent Union law providing more extensive protection'.

68 ECJ, Case C-57I/Io Kamberaj $v$ IPES [20I2] ECR I-oooo, paras 62-63 (where a caveat is also broached by further specifying that Article 6[3] of the TEU should not be read as indirectly extending the primacy of EU law to the ECHR, because this provision 'does not govern the relationship between the ECHR and the legal systems of the Member States, nor does it lay down the consequences to be drawn by a national court in case of conflict between the rights guaranteed by that convention and a provision of national law').

69 For a general overview on Article 52(3) of the ChFR as incorporation clause, which would fall beyond the scope of this paper, see G. Ziegenhorn, Der Einfluss der EMRK im Recht der EU-Grundrechtecharta (Duncker \& Humboldt, Berlin, 2009).

70 W. Weiß, 'Human Rights in the EU: Rethinking the Role of the European Convention on Human Rights After Lisbon', 7 (I) European Constitutional Law Review (20II) 64-95, at 64. See also M. Borowski, 'Titel VII Allgemeine Bestimmungen über die Auslegung und Anwendung der Charta', in J. Meyer (ed), Charta der Grundrechte der Europäischen Union (3rd ed., Nomos, Baden-Baden, 20II) 628-72I (stating, at 687, that Article 52[3] of the ChFR operates as a 'Transferklausel ... die -unabhängig vom jeweiligen Wortlaut- zur inhaltlichen Identität der einander entsprechenden Rechte in der Charta und in der EMRK führt', which entails the 'Übernahme der entsprechenden EMRK-Bestimmungen in toto'; and further arguing, at 690, that '[ü]ber die Transfer- oder Inkorporationsklausel des Art. 52 Abs. 3 wird nahezu der gesamte materielle Grundrechtsschutz der EMRK und ihrer (Zusatz)Protokolle übernommen ... Es handelt sich -untechnisch gesprochen- um nichts anderes als um einen „materiellen Beitritt“ der Union zur EMRK ... Dieser materielle Beitritt erübrigt aber keineswegs den in Art. 6 Abs. 2 EUV vorgesehenen formellen Beitritt der Union zur EMRK. Denn nur so -über die damit verbundene Aussenkontrolle durch den EGMR- kann der Gefahr von Rechsprechungsdivergenzen letzlich wirksam begegnet werden').

7 See Explanations relating to the Charter of Fundamental Rights [2007] OJ C 303/r7 (stating that '[p]aragraph 3 [of Article 52] is intended to ensure the necessary consistency between the Charter and the ECHR by establishing the rule that, in so far as the rights in the present Charter also correspond to rights guaranteed by the ECHR, the meaning and scope of those rights, including authorised limitations, are the same as those laid down by the ECHR ...The reference to the ECHR covers both the Convention and the Protocols to it' [emphasis added]). But see the Opinion of Advocate General Cruz Villalón in Case C-6r7/ro Åkerberg Fransson, para 7I (arguing that Article 52[3] of the ChFR does not incorporate into EU law those Protocols of the ECHR that has not been ratified so far by all the EU Member States). Against this view, see S. Peers and S. Prechal, 'Article 52 - Scope and Interpretation of Rights and Principles', in S. Peers, T. Hervey, J. Kenner and A. Ward (eds), supra, n. 65, I455-1538, at I494.

72 See Explanations relating to the Charter of Fundamental Rights [2007] OJ C 303/r7 (further stating that ' $[t]$ he meaning and the scope of the guaranteed rights are determined not only by the text of those instruments [the ECHR and the Protocols], but also by the case-law of the European Court of Human Rights and by the Court of Justice of the European Union' [emphasis added]). See also ECJ, C-400/Io PPU JMcB v LE [2010] ECR 0000, para 53, referring to Article 52(3) of 
Therefore, the ECHR operates as a minimum standard below which the protection granted by EU law to fundamental rights via the ChFR cannot fall ${ }^{3}$. Should there be any case in which the ECHR may be claimed to afford greater protection than EU law by itself, the latter would be required to secure at least the same protection granted under the former. The ECHR can be then invoked where an additional benefit should be expected ${ }^{74}$.

As far as relevant here, both fundamental rights upon which protection can be granted under the ECHR to the enforcement of ICSID awards are also protected under EU law itself. Whereas property is secured by Article 17 of the ChFR 75 , so is also the right of access to court by its Article $47(2)^{76}$.

On the one hand, the scope of Article $17 \mathrm{ChFR}$ has been broadly construed by the ECJ as generally encompassing 'rights with an asset value creating an established legal position under the legal system, enabling the holder to exercise those rights autonomously and for his benefit'77. Even without relying on the ECHR via Article 52(3) of the ChFR, this broad interpretation would appear sufficient to protect claims of an economic value $e^{-8}$, such as final and binding arbitral awards that have 'given rise to

the Charter for concluding that 'Article 7 contains rights corresponding to those guaranteed by Article 8(I) of the ECHR [and] must therefore be given the same meaning and the same scope as Article 8(I) of the ECHR, as interpreted by the caselaw of the European Court of Human Rights' (emphasis added).

73 So can it be inferred from the Explanations relating to the Charter of Fundamental Rights [2007] OJ C 303/17. This thesis has been explicitly confirmed by several Advocates Generals. See Opinions in Case C-69/ro Diouf [20II] ECR I-715I, para 47; Case C-282/Io Dominguez [2012] ECR I-oooo, para 85; Joined Cases C-44I/Io and C-493/ro NS and ME, paras I45, 148, I55; Case C-I20/Io European Air Transport [2011] ECR I-7865, paras 79-80. See also ECJ, Joined Cases C-92/o9 and C-93/o9 Volker und Markus Schecke and Eifert v Land Hessen [2010] ECR I-IIO63, paras 5I-52.

74 See Opinion of the Advocate General Kokott in Case C-398/13 P Inuit Tapiriit Kanatami v Commission [2015] ECR I-oooo, paras 69-70 (arguing that it is not clear in the present case to what extent the ECHR -whether in conjunction with Article 6(3) TEU or with the first sentence of Article 52(3) of the Charter- might thus impose higher requirements on the EU legislature than the Charter cited by the General Court. In their appeal [the appellants] have not put forward any specific arguments in this regard and they failed to provide an explanation in reply to my express enquiry at the hearing. It is not therefore evident in this case what additional benefit a reference by the General Court to the ECHR, the absence of which is criticized by the appellants, might have had or to what extent that lack of reference could result in the setting-aside of the judgment under appeal').

75 Article $\mathrm{I} 7 \mathrm{I}$ ( ) of the ChFR provides that '[e]veryone has the right to own, use, dispose of and bequeath his or her lawfully acquired possessions. No one may be deprived of his or her possessions, except in the public interest and in the cases and under the conditions provided for by law, subject to fair compensation being paid in good time for their loss. The use of property may be regulated by law in so far as is necessary for the general interest.'.

${ }^{76}$ Article $47(2)$ of the ChFR provides that '[e]veryone is entitled to a fair and public hearing within a reasonable time by an independent and impartial tribunal previously established by law. Everyone shall have the possibility of being advised, defended and represented'.

77 ECJ, Case C-283/II, Sky Österreich GmbH v Österreichischer Rundfunk [20I3] ECR I-oooo, para 34.

${ }_{78}$ See N. Bernsdorf, 'Artikel I7', in Jürgen Meyer (ed), Charta der Grundrechte der Europäischen Union (3rd ed, Nomos, Baden-Baden, 20II) 30I-3I2, at 306, similarly arguing that '[i]n diese weite Auslegung können auch solche Rechte einbezogen sein, die in den mitgliedstaatlichen Rechtsordnungen (zivilrechtlich und/oder verfassungsrechtlich) nicht ausdrücklich als „Eigentum“ namhaft gemacht bzw. ausgestaltet sind. Neben dem klassischen Eigentum an beweglichen Sachen werden sämtliche wohlerworbenen vermögenswerten Rechte („droits acquis“/,acquired rights“) geschützt'. See also F. Wollenschläger, 'Article $\mathrm{I} 7(\mathrm{r})$ ', in S. Peers, T. Hervey, J. Kenner and A. Ward (eds), supra, n. 65, 465-487, at 472 (arguing that '[p]roperty extends to all pecuniary rights assigned to the individual in her/his private interest and as an exclusive entitlement ... Hence, the right to property encompasses not only moveable and immoveable property but also immaterial positions like claims of an economic value'). 
a debt in [the applicant's] favour that [is] sufficiently established to be enforceable 79 . Should this not appear sufficiently clear, the scope of Article I7 ChFR would be then required to be enlarged in accordance with Article I of Protocol No I of the ECHR, as the ECJ has already corroborated in its own case-law ${ }^{80}$.

On the other hand, Article $47(2)$ of the ChFR has been interpreted as the equivalent of Article 6(I) of the $\mathrm{ECHR}^{8 \mathrm{r}}$. Despite this provision having generated copious case-law ${ }^{82}$, the ECJ has not so far addressed the question whether the right of access to court enshrined therein may be considered to comprise the right to enforcement of judicial decisions or arbitral awards ${ }^{83}$.

Yet Article $47(2)$ of the ChFR is considered to have been originally conceived as comprising all the guarantees afforded by the $\mathrm{ECHR}^{84}$. And such result, as in the case of property rights under Article $\mathrm{I} 7$ of the ChFR, is ultimately guaranteed by relying on the ECHR via Article 52(3) of the ChFR. Indeed, the case-law of the ECJ provides relevant evidence on the large extent to which Article $47(2)$ of the

79 See supra, n. 26.

80 See ECJ, Case C-398/13 P Inuit Tapiriit Kanatami v Commission [2015] ECR I-oooo, para 6I (where Article 17 of the ChFR is construed by arguing that it is apparent from the case-law of the European Court of Human Rights relating to Article I of Protocol No I to the ECHR, which should be taken into consideration in accordance with Article 52(3) of the Charter, that future income cannot be considered to constitute 'possessions' that may enjoy the protection of that article unless it has already been earned, it is definitely payable or there are specific circumstances that can cause the person concerned to entertain a legitimate expectation of obtaining an asset' [emphasis added]).

8I See ECJ, Case C-279/o9 DEB v Germany [20IO] ECR I-I3849, para 32 (stating that '[a]ccording to the explanations relating to that article, which, in accordance with the third subparagraph of Article 6(I) TEU and Article 52(7) of the Charter, have to be taken into consideration for the interpretation of the Charter, the second paragraph of Article 47 of the Charter corresponds to Article 6(I) of the ECHR'). See also ECJ, Case C-396/II Radu [20I3], para 32 (stating that Articles 47 and 48 of the ChFR generally correspond to Article 6 ECHR).

${ }_{82}$ For an updated overview, see S. Prechal, 'The Court of Justice and Effective Judicial Protection: What Has the Charter Changed?', in C. Paulussen, T. Takács, V. Lazić, B. Van Rompuy (eds), Fundamental Rights in International and European Law: Public and Private Law Perspectives (TMC Asser Press, The Hague, 2016) I43-I57.

83 This has not prevented some scholars from suggesting Article $47(2)$ of the ChFR to comprise such a right. See M. Šikić and L. Ofak, 'Pravo na izvršenje upravnosudskih odluka kao jamstvo poštenog suđenja' ('Right to enforcement of administrative court decisions as guarantee to a fair trial'), 52 (I) Zbornik radova Pravnog fakulteta u Splitu ('Collected papers of the Law Faculty of the University of Split') (2015) 203-22I (arguing that Article 47 of the ChFR should be interpreted as guaranteeing the implementation of binding court decisions so as the right to a fair trial enshrined therein is not to be deprived of any effect); J. Adolphsen, 'Aktuelle Fragen des Verhältnisses von EMRK und Europäische Zivilprozessrecht', in J. Renzikowski (ed), Die EMRK im Privat-, Straf- und Öffentlichen Recht (Schulthess Juristischer Verlag, Zürich, 2004) 398I, at 73 (arguing that '[d]ie Aufnahme einer den Zugang zu einem Gericht garantierenden Bestimmung in die GrundrechteCharta ist zum jetzigen Zeitpunkt, an dem die Bildung eines einheitlichen europäischen Rechtsraums mit hohem Tempo vorangeht, nur dahin auszulegen, dass Art. 47 Abs. 2 Grundrechte-Charta auch die Anerkennung und Vollstreckung von Entscheidungen der Mitgliedstaaten garantiert'). Besides, the case-law of the ECJ on mortgage enforcement proceedings initiated with the Aziz decision (Case C-415/II) provides evidence on the extent to which Article 47(2) of the ChFR may have clear relevance for the enforcement of court decisions. See, as the most recent authority, C-I69/i4 Juan Carlos Sánchez Morcillo and María del Carmen Abril García v BBVA SA [2014] ERC I-oooo.

${ }^{8}$ See Explanations relating to the Charter of Fundamental Rights [2007] OJ C 303/17 (explicitly arguing, with regard to Article 47[2] of the ChFR, that in all respects other than their scope, the guarantees afforded by the ECHR apply in a similar way to the Union'. See also ECJ, Chalkor AE Epexergasias Metallon v Commission [20II] ECR I-oooo, para 5I (stating that 'Article 47 of the Charter implements in European Union law the protection afforded by Article 6(I) of the ECHR. It is necessary, therefore, to refer only to Article 47'); Europese Gemeenschap v Otis NV and Otbers [2012] ECR I-oooo, para 47 (similarly arguing that 'Article 47 of the Charter secures in EU law the protection afforded by Article 6(I) of the ECHR. It is necessary, therefore, to refer only to Article 47'). 
ChFR is already being construed under the strong influence of Article 6(I) of the ECHR ${ }^{85}$. Suffice it here to mention how the ECJ has recently been required to review the standard of judicial protection in the field of competition in accordance with the case-law of the ECtHR ${ }^{86}$.

In practical terms, several consequences can be inferred from these findings. To begin with, the fundamental rights enshrined in Articles 17 and $47(2)$ of the ChFR, interpreted in the light of the ECHR via Article 52(3) of the ChFR, must be weighed against the objectives pursued by EU law when the latter is operated against the enforcement of ICSID awards. For, as the ECJ has repeatedly stated, fundamental rights 'may be restricted, provided that the restrictions in fact correspond to objectives of general interest pursued by the measure in question and that they do not involve, with regard to the objectives pursued, a disproportionate and intolerable interference which infringes upon the very substance of the rights guaranteed ${ }^{87}$.

That is to say that EU law may impose restrictions on the enforcement of ICSID awards that would be compatible with the ECHR ${ }^{88}$, but not with the ICSID Convention, which only tolerates restrictions imposed by the rules on sovereign immunity from execution ${ }^{89}$. Were that the case, the

85 See ECJ, Case C-279/o9 DEB v Germany [2010] ECR I-I3849, para 32 (equating Article 47 of the ChFR to Article 6(I) of the ECHR); Case C-396/Ir Radu [20I3] ECR I-oooo, para 32 (equating Articles 47 and 48 of the ChFR to Article 6 ECHR); Case C-300/II, ZZ v Secretary of State for the Home Department [2013] ECR I-oooo (where State security and judicial protection are balanced against each other similarly as in the case of ECtHR, Cbabal $v$ United Kingdom [1996], albeit without explicitly referring thereto); Joined Cases C-4II/IO and C-493/Io NS v Secretary of State for the Home Department [20II] ECR I-oooo, para 90 (explicitly relying on ECtHR, MSS v Belgium and Greece [20II]); Melloni v Ministerio Fiscal [2013] ERC I-oooo, paras 49-50 (confirming the possibility for the accused to waive the right to appear in person at his trial, as part of the right to a fair trial, arguing that 'this interpretation of Articles 47 and 48(2) of the Charter is in keeping with the scope that has been recognized for the rights guaranteed by Article 6(I) and (3) of the ECHR by the case-law of the European Court of Human Rights').

86 In Menarini Diagnostics SRL $v$ Italy [20II], the ECtHR equated administrative fines in the field of competition law to criminal penalties for the purposes of Article 6(I) of the ECHR. Therefore, administrative decisions imposing fines are required to be subject to review by judicial bodies having full jurisdiction. The ECJ then reviewed its own case-law, which up until then had always held that fines imposed by the European Commission in the field of competition law were only subject to limited judicial review. See ECJ, Case C-50I/II Schindler Holding and Others v Commission [2013] ECR I-oooo; Case C-583/13 Deutsche Babn AG and Other v Commission [2015] ECR I-oooo. See also Opinion of Advocate General Sharpton in Case C-272/09 P KME Germany [20II] ECR I-oooo, para 67.

87 ECJ, Joined Cases C-317/08 to C-320/08 Alassini and Others [2010] ECR I-2213, para 63; Case C-4I8/II Texdata Software GmbH [2013] ECR I-oooo, para 84. See also ECJ, Joined Cases C-92/o9 and C-93/o9 Volker und Markus Schecke and Harmut Eifert $v$ Land Hessen [2010] ECR I-IIO63, para 77 (where the ECJ argues that, for ruling on the validity of the EU Regulation at stake in casu, it is necessary to determine whether the Council and the Commission have balanced the EU interest in guaranteeing the transparency of its acts and ensuring the best use of public funds against the interference with the right of the beneficiaries concerned to respect for their private life in general and to the protection of their personal data in particular, bearing in mind that derogations and limitations in relation to the protection of personal data must apply only in so far as is strictly necessary).

88 See Explanations relating to the Charter of Fundamental Rights [2007] OJ C 303/17 (" $[$ t] he level of protection afforded by the Charter may not, in any instance, be lower than that guaranteed by the ECHR, with the result that the arrangements for limitations may not fall below the level provided for in the ECHR' [emphasis added]). See also ECJ, Case CII/95 Commission v Belgium [1996] ECR I-4II5, paras 43-44 (arguing a contrario that the fact that a compulsory authorization system applying to the television sector is not contrary to Article to of the [ECHR] does not prevent such a system from being contrary to [EU] law'). See also S. Peers, 'Taking Rights Away? Limitations and Derogations', in S. Peers and A. Ward (eds) The European Union Charter of Fundamental Rights (Hart, Oxford, 2004) I4I-I82 (analyzing to what extent EU law is bound by the ECHR in imposing restrictions to fundamental rights).

89 Whereas Article 54(I) of the ICSID Convention mandates every State party to 'enforce the pecuniary obligations imposed by [an ICSID award] as if it were a final judgment of a court in that State', Article 55 specifies that '[n]othing in 
operation of the ECHR within the framework of EU law could not prevent a treaty conflict from arising between the latter and the ICSID Convention ${ }^{\circ}$.

Be that as it may, it is not less important to note that the requirement to balance the fundamental rights enshrined in Articles 17 and $47(2)$ of the ChFR against the objectives pursued by EU law is addressed to both EU institutions and national courts of the Member States. Should EU law be operated in the framework of enforcement proceedings conducted before the national courts of any Member State, it is clear that such proceedings are 'implementing EU law' for the purpose of Article 5I(I) of the $\mathrm{ChFR}^{91}$, as long as the decision to grant enforcement may be potentially affected by EU law ${ }^{92}$. The same applies for the case of EU institutions. Article 5I(I) of the ChFR would similarly require the European Commission and the ECJ to balance the EU objectives opposing enforcement against Articles 17 and $47(2)$ of the ChFR in the framework of an infringement proceeding being

Article 54 shall be construed as derogating from the law in force in any Contracting State relating to immunity of that State or of any foreign State from execution'. In addition, it should be noted that the enforcement of obligations other than pecuniary is not prevented by the ICSID Convention from being subject to further restrictions. See C. Schreuer, 'NonPecuniary Remedies in ICSID Arbitration', 20 (4) Arbitration International (2004) 325-332 (arguing, at 325, that ' $[t]$ he deliberations during the drafting of the ICSID Convention show clearly that the restriction in Article 54 to pecuniary obligations was based on doubts concerning the feasibility of an enforcement of non-pecuniary obligations and not on a desire to prohibit tribunals from imposing such obligations', and concluding, at 332, that '[ICSID] [t]ribunals imposing such non-pecuniary obligations should keep the impossibility of enforcing them in mind'). See also T. W. Wälde, 'Remedies and Compensation in International Investment Law', Report of the ILA Committee on International Law of Foreign Investment (First Draft Report, July 2005) at 25 (suggesting the hypothesis that the enforcement of non-pecuniary obligations imposed by ICSID awards be governed by the New York Convention, whose Article 5 contains a set of grounds for refusing enforcement). As T. W. Wälde points out (ibid, at 34), the possibility for ICSID awards to impose non-pecuniary obligations depends on the applicable international investment agreement. Should this be the case, ICSID awards can also give States the alternative choice between specific remedies and pecuniary compensation. See Antoine Goetz $v$ Burundi, ICSID Case No ARB/95/3, Award of $10^{\text {th }}$ February 1999 (where Burundi was given the choice between revoking an administrative act or awarding pecuniary compensation to the claimants).

90 This treaty conflict is to be resolved by applying the rules contained in the Vienna Convention on the Law of the Treaties. See A. Ali Ghouri, 'Resolving Incompatibilities of Bilateral Investment Treaties of the EU Member States with the EC Treaty: Individual and Collective Options' 16 (6) European Law Journal (2010) 806-830.

9r Article 5I $(\mathrm{I})$ of the ChFR provides that " $[\mathrm{t}]$ he provisions of this Charter are addressed to the institutions and bodies of the Union with due regard for the principle of subsidiarity and to the Member States only when they are implementing Union law. They shall therefore respect the rights, observe the principles and promote the application thereof in accordance with their respective powers'.

92 See ECJ, Case C-617/Io Akerberg Fransson [2013] ERC I-0000, para 2I (arguing that ' $[s]$ ince the fundamental rights guaranteed by the Charter must [...] be complied with where national legislation falls within the scope of [EU] law, situations cannot exist which are covered in that way by [EU] law without those fundamental rights being applicable. The applicability of [EU] law entails applicability of the fundamental rights guaranteed by the Charter'); Case C-206/I3 Cruciano Siragusa $v$ Regione Sicilia [20I4] ERC I-oooo, para 25 (stating that '[i]n order to determine whether national legislation involves the implementation of EU law for the purposes of Article 5I of the Charter, [one] of the points to be determined [is] whether there are specific rules of EU law on the matter or capable of affecting it'). 
initiated against a Member State granting enforcement ${ }^{93}$ or a preliminary reference requested by a national court at the enforcement stage ${ }^{94}$.

Finally, a last reference must be made to the possibility of EU law being operated against the enforcement of ICSID awards for the purpose of protecting fundamental rights. For, as in the case of Article 6(I) of the ECHR, Article $47(2)$ of the ChFR may similarly oppose the enforcement of judgments or awards considered to have been rendered in breach of fundamental rights granted by EU law ${ }^{95}$. For this scenario to be properly understood, a distinction must be made between cases in which EU law is operated against enforcement on the basis of competition or state aid rules ${ }^{96}$ and those in which it is operated in order to protect fundamental rights.

In the latter cases, it should be noted that the ECHR may support, or even mandate, that ICSID awards be denied enforcement for violating EU law ${ }^{97}$. This would only be the case when EU law is operated in order to protect fundamental rights ${ }^{8}$, be it through the provisions contained in the ChFR

93 As it should have been done in the case of the infringement proceeding initiated against Romania for complying with the pecuniary compensation imposed by the ICSID award rendered in Micula $v$ Romania (supra, n. 25). See European Commission, Decision (EU) 20I5/1470 of 30 March 2015 on State aid SA.38517 (2014/C) (ex 2014/NN), para 75 (referring to the arguments submitted by the claimants 'noting that the Commission's practice in State aid cases in general does not sufficiently safeguard the alleged beneficiaries' procedural rights, and is, by failing to provide an effective remedy, contrary to Article 6(I) of the European Convention on Human Rights and Article 47 of the EU's Charter of Fundamental Rights').

94 See Frankfurt Court of Appeal (OLG Frankfurt am Main), Decision ('Beschluss') of I8 December 2014, 26 Sch 3/13 (Eureko $v$ Slovakia), para 63 (stating that '[d]ie Entscheidung des [Investitions] Schiedsgerichts unterliegt zudem auch insoweit gemäß der Rechtsprechung des EuGH der durch Einrichtung entsprechender Rechtsbehelfe begründeten Prüfungskompetenz mitgliedsstaatlicher Gerichte, die die Anwendung des maßgeblichen EU-Rechts gegebenenfalls auch mittels eines Vorabentscheidungsersuchens an den EuGH zu gewährleisten haben').

95 See ECJ, Case C-6rg/10 Trade Agency Ltd $v$ Seramico Investments Ltd [2012] ECR I-oooo, para 62 (interpreting the Brussel I Regulation in order to conclude that the courts of Member States can only refuse to enforce a judgment where 'only if it appears to the court, after an overall assessment of the proceedings in light of all the relevant circumstances, that that judgment is a manifest and disproportionate breach of the defendant's right to a fair trial referred to in Article $47(2)$ of the Charter' [emphasis added]).

96 That would be the case, for instance, when the compensation awarded by the arbitral tribunal is considered to amount to state aid prohibited by EU law, as in the above mentioned case of Micula $v$ Romania, see supra, n. 25.

${ }_{97}$ The case-law of the ECtHR provides several examples in which the infringement of EU law may further amount to violations of fundamental rights protected under the ECHR. See ECtHR, Scoppola $v$ Italy [2009], para ros (where Article 7 of the ECHR was construed by relying on EU law); Micallef $v$ Malta [2009], para 32 and 78 (where EU law was taken into account in order to interpret Article 6 of the ECtHR); Aristimuño Mendizábal v France [2006], para 69 (where the right for respect to family life enshrined in Article 8 of the ECHR was interpreted by the ECtHR in the light of EU law); Dangeville $v$ France [2002], Cabinet Diot and Gras Savoye $v$ France [2003], and Aon Conseil et Courtage v France [2007] (where violations of Article I of Protocol No I of the ECHR were established relying on rights conferred by the Sixth VAT Directive); Maslov v Austria [2008], para 82 (where the protection granted to minors from expulsion by EU law was considered in order to assess a violation of Article 8 of the ECtHR); Saddi $v$ United Kingdom [2008], paras 40 and 56 (where protection granted to asylum-seekers by EU law is taken into account in order to assess a violation of Article 5(I) of the ECtHR). Finally, there is a long-settled line of decisions in which the ECtHR has repeatedly stated that a refusal to submit a preliminary reference to the ECJ may amount to a violation of Article 6(I) of the ECHR. See ECtHR, Societe Divagsa v Spain [1993]; Peter Moosbrugger v Austria [2000]; Wynen and Centre hospitalier interrégional Editb-Cavell v Belgium [2002]; Canela Santiago v Spain [200I]; Pedersen and Pedersen v Denmark [2003]; Coëme and Others v. Belgium [2000]; Lutz Jobn v Germany [2007]; Claus and Heike Herman v Germany [2009]; Ullens de Schooten and Rezabekv Belgium [20II].

${ }_{98}$ It should be noted that, under the ECHR, the presumption for an international organization to afford equivalent protection of fundamental rights can be rebutted 'where the protection in the particular case is regarded as manifestly deficient' (ECtHR, Bosphorus v Ireland [2005], para 156). EU law standards of protection may be taken into account for identifying a manifest deficiency. See C. Dautricourt, 'A Strasbourg Perspective on the Autonomous Development of Fundamental Rights in EU Law: Trends and Implications', Jean Monnet Working Paper Io/2010. 
or through other primary or secondary law provisions being indirectly operated in their support, as it could well be the case when the exercise of EU market freedoms support the exercise of fundamental rights or vice versa99.

\section{(D) CONCLUSIONS}

Several arguments have been here considered for suggesting a supportive relationship to operate between the ICSID Convention and the ECHR. This hypothesis is premised on the ascertainment that the judicial enforcement of arbitral awards rendered under the former may be granted further protection under the latter. Denial of enforcement to ICSID awards may concurrently amount to a violation of both Article I of Protocol No I and Article 6 of the ECHR. Yet for such protection to be granted under the ECHR, the arbitral system instituted within the framework of the ICSID Convention is required to protect fundamental rights in a manner which can be considered at least equivalent to that for which the ECHR provides.

Since the ECHR has been materially incorporated into EU law via Article 52(3) of the ChFR as a minimum standard for the protection of fundamental rights, both Articles $\mathrm{I} 7(\mathrm{I})$ and $47(2)$ of the ChFR must be construed in accordance with the case-law of the ECHR on Article I of Protocol No I and Article 6(I) of the ECHR. Should any provisions of EU law be operated against the enforcement of ICSID awards, both EU institutions and national courts of the EU Member States would be then required to balance the fundamental rights at stake against the objectives pursued by EU law. Finally, as a bar to enforcement, EU law may only be supported by the ECHR when its provisions are operated against the award in order to safeguard fundamental rights being also protected under the ECHR.

99 See European Court of Justice, C-260/89 Elliniki Radiophonia Tiléorassi v Dimotiki Etairia Pliroforissis [1991] I02925; C-159/90 The Society for the Protection of Unborn Children Ireland Ltd v Stephen Grogan and others [I99I] ECR I04685; C-60/00 Mary Carpenter v Secretary of State for the Home Department [2002] ECR I-06279. See also J. Cabrera Rodríguez, 'Derechos fundamentales y libertades económicas en el ordenamiento comunitario. La jurisprudencia Viking y Laval', 99 Revista Española de Derecho Constitucional (2013) 371-428, at 376 et seq; T. Kingreen, 'Fundamental Freedoms', in A. Von Bogdandy and J. Bast (eds), Principles of European Constitutional Law (2nd ed., Hart/Beck/Nomos, Oxford/Munich, 2010) $515-549$, at $543-545$. 